\title{
Verktøy kan gjenkjenne alvorlig sykdom hos barn tidlig
}

De fleste barneavdelinger har tatt i bruk pasientsikkerhetsverktøyet PedSAFE for å vurdere og oppdage alvorlig sykdom hos barn og unge.

\section{Forfattere}

\section{Tonje Holm Hjertaas}

Barnesykepleier og nasjonal nettverkskoordinator PedSAFE

Akershus universitetssykehus

\section{Anne Lee Solevåg}

Overlege

Akershus universitetssykehus

\section{Nøkkelord}

\section{PedSAFE Pevs Pediatrisk tidlig varslingsskår Pasientsikkerhet Barn}

Sykepleien 2017 105(61904)(e-61904)

DOI: https://doi.org/10.4220/Sykepleiens.2017.61904

\section{HOVEDBUDSKAP}

PedSAFE er et rammeverktøy for at helsepersonell lettere skal kunne vurdere og tidlig gjenkjenne alvorlig sykdom eller tilstand hos barn og ungdommer. PedSAFE-konseptet inkluderer teoretisk og praktisk trening i å vurdere etter ABCDE-algoritmen, kommunikasjonsverktøyet ISBAR og PEVS. Verktøyet ble utviklet i 2011 av leger og sykepleiere ved Ahus. 
Pediatric Systematic Assessment and communication

For preventing Emergencies (PedSAFE) er et

rammeverktøy som ble utviklet av leger og sykepleiere i samarbeid med Avdeling for forskning og utvikling på Akershus universitetssykehus (Ahus). Verktøyet ble utviklet for at helsepersonell skulle bedre kompetansen i å systematisk vurdere og tidlig gjenkjenne alvorlig sykdom eller tilstand hos barn og ungdommer $(1,2)$.

Utviklingen av PedSAFE startet på Ahus i 2011 etter at sykehuset opplevde en kraftig økning i pasientgrunnlaget og på kort tid fikk flere alvorlig syke barn i avdelingen (1, 2). Etter dette har andre aktører, blant annet Sørlandet sykehus og Haukeland universitetssykehus, bidratt med å kvalitetssikre og videreutvikle konseptet.

Høsten 2016 ble den første nasjonale PedSAFEkonferansen holdt ved hjelp av midler fra Den norske legeforenings fond for kvalitetsforbedring og pasientsikkerhet. Konferansen avdekket flere områder brukerne av PedSAFE ønsker å arbeide videre med. På Ahus og blant andre brukere av PedSAFE arbeides det hele tiden med å forbedre og kvalitetssikre PedSAFE.

\section{PedSAFE}

PedSAFE-konseptet inkluderer teoretisk og praktisk trening i å vurdere etter ABCDE-algoritmen, kommunikasjonsverktøyet ISBAR og PEVS (se faktaboks og figur 1). En sentral del av PedSAFE er også jevnlige casetreninger. På Ahus avholdes disse ukentlig. Da øver leger og sykepleiere sammen på ABCDE-algoritmen og kommunikasjon ved hjelp av ISBAR. Casetreningene er mindre omfattende, men også mer tilgjengelige, enn fullskala simuleringsøvelser. Casetrening har ABCDE og ISBAR som læringsmål. Treningene varer totalt 30 minutter og gjennomføres i barnemottak hver uke. 


\section{Figur 1: Sentrale elementer i PedSAFE}

\section{PedSAFE}
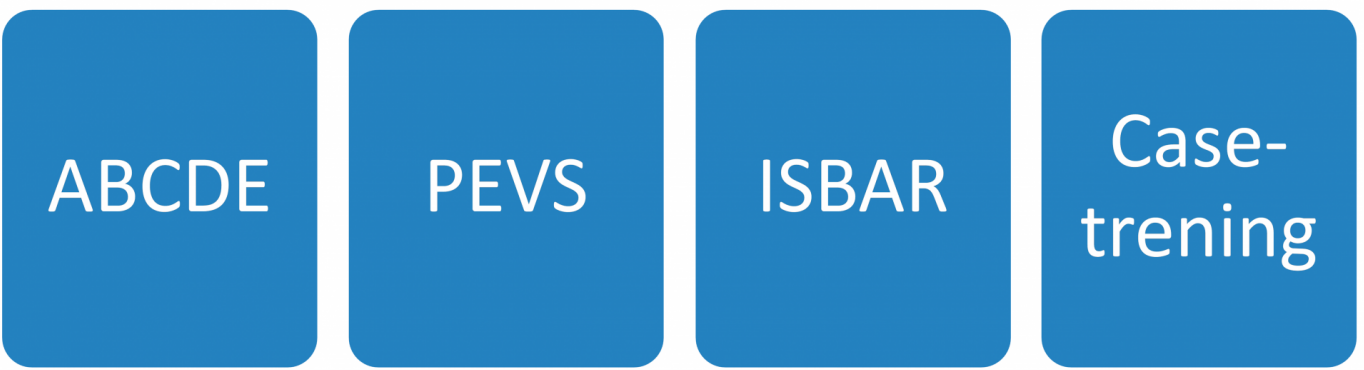

\section{ABCDE, PEVS OG ISBAR}

ABCDE: ABCDE-algoritmen er en mye brukt systematisk måte å vurdere pasientene på. Pasientene vurderes i rekkefølge etter følgende kategorier:

- Airways (luftveier)

- Breathing (respirasjon)

- Circulation (sirkulasjon)

- Disability (nevrologi)

- Exposure (helkroppsundersøkelse)

PEVS: Selve skåringsverktøyet Pediatrisk tidlig varslingsskår. Pasientene får poeng i kategoriene respirasjon, sirkulasjon og adferd, som summeres til en total PEVS-skår.

ISBAR: En modell for kommunikasjon mellom helsepersonell $i$ et behandlingsteam. ISBAR er et akronym og inneholder elementer som enhver samtale rundt pasienter bør inneholde:

- Identify (identifiser): Presenter deg, din funksjon og avdeling, pasientens navn og fødselsdato.

- Situation (situasjon): En presis beskrivelse av problemet.

- Background (bakgrunn): Relevant og kortfattet informasjon om forhistorien/innleggelsesdiagnosen. 
- Assessment (vurdering): Respirasjonsfrekvens, puls, kapillærfylning, BT, PEVS er ...

- Recommendation (anbefaling): «Kan jeg gi barnet ...?» «Hva vil du anbefale?» «Jeg vil at du skal komme nå!»

\section{Bruk av verktøyet}

I dag brukes PedSAFE av leger og sykepleiere på 19 av 21 barneavdelinger i Norge. Våren 2017 er det enda et sykehus som tar i bruk PedSAFE i sin avdeling.

Flere internasjonale studier på ulike varianter av Pediatrisk tidlig varslingsskår (PEVS) har vist at slike verktøy kan forutsi flere timer i forkant hvilke pasienter som kan trenge intensivbehandling $(3,4)$. Målet med PedSAFE er å få et rammeverk for tidlig gjenkjenning av risikopasienten, tidlig intervensjon og forhåpentlig forebygging av forverring $\mathrm{i}$ sykdomsbildet.

\section{«I dag brukes PedSAFE av leger og sykepleiere på 19 av 21 barneavdelinger i Norge.»}

Det er ønskelig at PedSAFE etter hvert også tas i bruk prehospitalt. Dette vil forhåpentlig bidra til at pasienten blir bedre ivaretatt gjennom hele behandlingskjeden, fra fastlege/legevakt til spesialisthelsetjenesten og tilbake igjen, og at behandlingen har bedre kvalitet. Når man bruker PEVS til å vurdere syke barn, får man en objektiv og strukturert vurdering av det syke barnet. Da blir sjansen større for å kunne gjenkjenne en alvorlig tilstand på et tidlig tidspunkt, uavhengig av erfaringsnivået til den som vurderer barnet.

\section{Atferdsskår}


I diskusjonene som fulgte i etterkant av konferansen, ser vi at det oftest er PEVS-skåren for atferd, AVPU, som skåres feil, eller som ikke skåres fordi sykepleieren ikke vekker barnet. AVPU er i dag bygget opp ved at man gir følgende poeng:

- 0 poeng for «Alert»: våken med normal kontakt/interesse for omgivelsene,

- 1 poeng for «Voice»: slapp/somnolent, reaksjon ved tiltale/berøring,

- 2 poeng for «Pain»: reaksjon kun ved smertestimuli, og

- 3 poeng for «Unresponsive»: ingen reaksjon selv ved smertestimuli (1).

Vi ser at «Pain» feiltolkes noen ganger og brukes der barnet har smerte, og ikke der barnet kun reagerer på smertestimuli. En annen gjentakende feil er at «Alert» brukes der barnet skulle vært skåret til «Voice». Det er derfor en pågående diskusjon om å endre dagens AVPU til noe som er mer likt den originale Brighton PEWS (5). Man vil da gi 0 poeng for «våken med normal kontakt, interesse for omgivelsene», 1 poeng for «slapp, redusert aktivitet, sover», 2 poeng for «irritabelt/somnolent barn» og 3 poeng for «bevisstløs, kramper, redusert smerterespons».

Noen PedSAFE-brukere mener at dagens AVPU fungerer godt nok i seg selv, men at forklaringen av de ulike kategoriene bør bli bedre. Andre mener imidlertid at den originale Brighton PEWS vil være best i bruk. PedSAFE-gruppen på Ahus, det nasjonale PedSAFE-styret med representanter fra ulike helseforetak og andre aktører jobber for tiden med å etablere en nasjonal konsensus rundt optimalisering av atferdsskala i PEVS.

\section{PEVS i pasientjournal}


PEVS i elektronisk pasientjournal er et av

satsingsområdene. På konferansen i oktober ble en arbeidsgruppe fra Ahus og Østfold etablert. Gruppen arbeider videre med PEVS i elektronisk pasientjournal, og PEVS vil i første omgang bli integrert i den elektroniske kurveløsningen MetaVision i løpet av 2017. Sykehuset Østfold på Kalnes startet opp med elektronisk PEVS-skjema i februar.

\section{Nasjonale retningslinjer}

Etter hvert som flere avdelinger har tatt i bruk PedSAFE, har vi sett at flere barneavdelinger har laget sine egne tilpassete versjoner av PEVS. PedSAFEgruppen på Ahus har blitt oppmerksom på at det finnes seks ulike PEVS-skjemaer som hadde små eller store forandringer fra det som opprinnelig ble laget i Norge. Med flere ulike skjemaer mister PEVS noe av sin funksjon siden man ikke lenger bruker samme verktøy; en PEVS på 5 på et sykehus betyr ikke nødvendigvis det samme som 5 på et annet sykehus.

Multisentervaliderings- og forbedringsstudier på PEVS er dessuten bare mulige dersom det er det samme verktøyet som brukes. Derfor ønsker vi å etablere nasjonal konsensus rundt retningslinjer for bruk av PEVS og PedSAFE. Når vi skal utarbeide nasjonale retningslinjer, er det nødvendig å ha med representanter fra alle helseregioner. Arbeidet har nå så vidt startet opp i regi av det nasjonale PedSAFE-styret, og vi håper å ha ferdig en nasjonal anbefaling for bruk av PEVS og PedSAFE innen høsten 2017. 
Arbeidet med PedSAFE har til nå i stor grad vært drevet av et fătall sykehus og med stor egeninnsats fra enkeltpersoner. PedSAFE har vokst til å bli et etablert pasientsikkerhetsverktøy til bruk på de minste pasientene i helsevesenet. Da Helsedirektoratet lanserte sin pasientsikkerhetskampanje «I trygge hender 24-7», var det lite i den som var myntet direkte på barn. Fra Ahus har vi derfor sendt gjentatte henvendelser til Helsedirektoratet der vi ber om at de ser på muligheten for å ta PedSAFE inn i pasientsikkerhetsprogrammet.

\section{PEVS til triagering}

Chapman og Grocott (6) konkluderer med at PEVS kan bidra til å identifisere risikopasienter i mottak og forutsi innleggelse i intensivavdeling. De presiserer likevel at PEVS ikke bør brukes i mottak som et rent triageringsverktøy. Flere av landets barneavdelinger benytter i tillegg til PEVS egne triageringsverktøy som RETTS-p, SATS eller Manchester triage i mottak. PEVS har aldri blitt validert for triagering og ble heller ikke utviklet for slik bruk.

Gold, Mihajo og Cohen (3) så på bruken av PEVS i akuttmottak og konkluderte med at PEVS kan brukes til datasamling, og at forhøyet skår gir en indikasjon på hvem som kan trenge innleggelse eller intensivbehandling. Imidlertid konkluderte de med at verktøyet manglet flere kriterier for å avgjøre forløp eller forutsi ytterligere forverring i mottak.

PEVS, sammen med de andre elementene i PedSAFE, danner likevel et solid grunnlag for mottak og vurdering av syke barn. St. Olavs Hospital og Ahus har nå planer om et samarbeid om en eller flere studier der PEVS og RETTS-p sammenliknes i mottakssituasjoner.

\section{Nyfødt}


Mens verktøy for tidlig gjenkjenning av

sykdomsforverring hos voksne og barn begynner å bli

vanlig akseptert praksis, er det mindre utbredt $\mathrm{i}$

nyfødtpopulasjonen. Internasjonalt har man etter hvert begynt med liknende verktøy beregnet for nyfødte. Her hjemme utførte Mortensen og medarbeidere et grundig litteratursøk (7) der de gikk gjennom ulike tilgjengelige verktøy beregnet på nyfødte.

\section{三 «Internasjonalt har man etter hvert begynt med liknende verktøy beregnet for nyfødte.»}

Flere skjemaer har blitt vurdert av en prosjektgruppe ved Sørlandet sykehus og Ahus, før de til sist landet på en modifisert og oversatt versjon av Newborn Early Warning Trigger and Track (NEWTT), oversatt til Tidlig varslingsskår - nyfødt» (TVS-N). Ahus og Sørlandet sykehus har gjennomført et pilotprosjekt på friske nyfødte på Føde og barsel. Førde skal starte med å registrere både friske og syke nyfødte fra 2017, og Ahus skal prøve ut skjemaet på barn som er innlagt på nyfødtintensiv.

\section{Oppsummering}

PedSAFE er nå adaptert av de fleste barneavdelinger i landet. Vi har dermed fått et nettverk av fagfolk som snakker samme språk, noe som kan redusere antall barn som opplever en tilstandsforverring på grunn av kommunikasjonssvikt i barnets behandlerteam. Selv om de fleste barneavdelinger nå bruker konseptet, ønsker vi på sikt å få med fastleger, legevakten og ambulansetjenesten, slik at hele behandlingskjeden snakker samme språk.

Det er viktig at arbeidet drives fremover, og vi planlegger årlige nettverkskonferanser for å bidra til videre utvikling og kvalitetssikring av PedSAFE.

Ønsker du å bidra i dette arbeidet, ta gjerne kontakt på pedsafe@ahus.no. Du kan også følge PedSAFE på Facebook og på hjemmesiden. 


\section{Referanser}

1. Bjerke A, Moen E, Bråthen AB, Solevåg AL, Nakstad B. PedSAFE - et utdannings- og treningsprogram for helsepersonell som arbeider med barn og ungdom. Tidsskrift for Barnesykepleiere 2015;1:4-5.

2. Solevag AL, Karlgren K. Competences for enhancing interprofessional collaboration in a pediatrics setting: Enabling and hindering factors. J Interprof Care 2016;30(1):129-31.

3. Gold, D, Mihajlo L, Cohen D. Evaluating the pediatric early warning score (PEWS) system for admitted patients in the Pediatric Emergency Department. Society for Academic Emergency Medicine 2014 Nov;21(11):1249-56.

4. Agulnik, A, Forbes P, Stenquist N, RodriguesGalindo C, Kleinman M. Validation of the pediatric early warning score in hospitalized pediatric oncology and hematopoietic stem cell transplant patients. Pediatr Crit Care Med 2016 Apr;17(4):e146-53.

5. Monaghan, A. Detecting and managing deterioration in children. Pediatric Nurs 2005;17:32-5.

6. Chapman SM, Grocott, F. Systematic review of pediatric alert criteria for identifying hospitalized children at risk of critical deterioration. Intensive Care Medicine 2010;36(4):600-11.

7. Mortensen N, Augustsson, JH, Ulriksen J, Hinna UT, Schmölzer GM, Solevåg AL. Early warning- and track and trigger systems for newborn infants: A review. Journal of Child Health Care 2017;1:112-20. 